International Journal of Instruction e-ISSN: 1308-1470 • www.e-iji.net

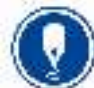

Article submission code: 20200302133403

Received: 02/03/2020 Revision: 16/09/2020
April 2021 • Vol.14, No.2

p-ISSN: 1694-609X

pp. 323-344

Accepted: 08/10/2020

OnlineFirst: 21/01/2021

\title{
Reflective Teaching Perceived and Practiced by EFL Teachers - A Case in the South of Vietnam
}

\author{
Do Minh Hung \\ Dong Thap University, Vietnam, dmhung@dthu.edu.vn \\ Pham Trut Thuy \\ Can Tho English Language Center, Vietnam, thuy3890@gmail.com
}

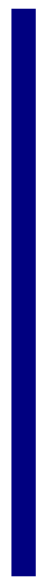

\begin{abstract}
Reflective teaching (RT) is one of the core components of teacher professional development. Owing to its substantive importance in teacher education, this component has been long recognized and widely examined in various approaches. However, it is not the case in Vietnam. Thus, the present study was done to investigate how RT was perceived and practiced by a local group of in-service EFL teachers in an English language center located in Can Tho City, South of Vietnam. Data were collected via a questionnaire, followed by a semi-structured interview. Results showed that all surveyed teachers held a positive perception towards RT values in professional development, and practiced all three types of in, on-, for-action reflections. Yet, in effect, they usually opted for only three strategies of workshop/training program, student feedback, and classroom walkthrough observation, while other RT strategies, such as journaling/diarywriting and video-recording, were scarcely used due to their workload-induced time constraint, fatigue, and limited knowledge of RT. Thereby, discussions and implications are provided.
\end{abstract}

Keywords: perception, practice, reflection, reflective teaching, EFL teacher

\section{INTRODUCTION}

English has been currently taught as a major foreign language at all levels of education (primary, secondary, and tertiary) throughout the country of Vietnam. In effect, English education as the most important foreign language starts from $3^{\text {rd }}$ Grade at primary schools up to tertiary education all over the country and English proficiency is one of the core competencies for most students. Thus, there should be qualified EFL teachers available meeting the country's needs. In this context, Vietnam's Ministry of Education and Training (MOET) has executed several approaches, which have been comprehensively and systematically endorsed in the National Foreign Languages Project 2008-2020 (MOET, 2008/2017). Among these approaches is the continual professional development for in-service EFL teachers by workshops or training programs. Upon this context, Truong (2017) reviewed the components of professional development in the

Citation: Hung, D. M., \& Thuy, P. T. (2021). Reflective Teaching Perceived and Practiced by EFL Teachers - A Case in the South of Vietnam. International Journal of Instruction, 14(2), 323-344. https://doi.org/10.29333/iji.2021.14219a 
relevant literature, and thereby he proposed a model of effective professional development programs to be implemented for EFL teachers in the country. In this proposed model, one phase is "At this stage, collaboration activities, as well as selfregulated plans from teachers, are encouraged. They are also asked to reflect upon what they have done and achieved after each step to make sure the program is smoothly implemented" (Truong, 2017, p.163). Meanwhile, on reviewing the literature on the concept of "reflection", Nguyen et al. (2015) posited, "Reflection is accredited as an essential component in the standards for teachers of the Organisation for Economic Cooperation and Development (OECD) countries. However, in Vietnam, reflection has maintained an unexplored area and a novel concept" (p.97). Accordingly, it also renders that a needed systematic inquiry on reflective teaching (RT) has not been established by educators and researchers in this country although RT in nature is one of the core elements for the success of all pedagogies, and it has been widely investigated from various angles and dimensions (see Cirocki \& Widodo, 2019; Garzon et al, 2018; Sinno, 2016; for example) in many countries around the world. The first study in Vietnam on RT issues was done by Nguyen et al. (2018), examining four teacher educators' reflective stories in Can Tho University, South of Vietnam. Their stories showed the inherent benefits of reflection on instructional activities. Following these initial research results on RT, the current study was designed to provide insights into RT perceived and practiced by a group of in-service EFL teachers working in a local English language center in Vietnam. Specifically, it was aimed to seek answers to three research questions: (1) What are the surveyed teachers' perceptions of RT? (2) How often and what strategies do these EFL teachers practice RT? (3) Do they face any difficulties in RT? Findings obtained from the current study is significant because it is expected to add further context-specific evidence to the existing body of knowledge about the nature of RT in effect, and also provide relevant information for Vietnam's educators about their prospective decisions in planning and execution of teacher professional development.

\section{LITERATURE REVIEW}

\section{What is reflection?}

Since reflection was first mentioned in language education by Dewey (1933), several definitions have been given by other linguists and researchers. Dewey defines reflection "involves not simply a sequence of ideas, but a consequence - a consecutive ordering in such a way that each determines the next as its proper outcome, while each in turns leans back on its predecessors" (1933, p.3). Thus, reflection is a result of a series of thoughts in which the following parts of reflective thought develop from the previous parts and assists one another; they are not a mixture of different kinds of thoughts; instead, they go through transitional phases. According to Postholm (2008), the word reflection is derived from a Latin word (re-flectio) meaning turn (re) and back (flectio). Consequently, reflection means turning back and thinking of something that already happened. In the context of teaching, pedagogical reflection or reflective teaching is searching for models in one's thinking about the classroom practice and enquiring the reason behind one's successful or unsuccessful lessons. Moreover, it is a kind of "a self- 
dialogue that not only allows practitioners to question, evaluate and problematize their teaching beliefs, knowledge and practices, but also leads to their transformation or reconstruction" (Cirocki \& Widodo, 2019, p.17).

\section{Benefits of reflective teaching}

Within the scope of the current study, the researcher only presents those RT benefits which are substantively practical in the context of teaching. Generally, this section will address four major benefits.

\section{(1) Raising awareness of teaching practice}

Many researchers considered reflection to be a very beneficial and constructive selfawareness raising activity for teachers. Pollard et al. (2014) stated that a very important aspect of RT is knowing one's self, and that teachers have both weaknesses and strengths, and classroom life tends to reveal these fairly quickly. Reflective practice predominantly helps teachers develop a more profound and richer understanding of their own teaching styles, methods, and techniques; and how effectively they teach (Ferraro, 2000).

(2) Gaining experiences and renovating instruction

Vazir (2006) noted that reflection involves reconstruction, and reconstruction is rebuilding old concepts and experiences to deal with the demands of present teaching situations. Furthermore, when the lesson does not go as planned, teachers often spend a moment to examine why it happened, what they should do to prevent it or how it would affect their teaching practice in the future. As a consequence, they will be well-prepared to deal with similar situations if they occur in the future. Richards (1995) supported that reflection might assist teachers to move away from suddenly intuitive or routine to reflective actions, while Qing (2009) argued that gaining experience in teaching helps teachers form their teaching strategies for dealing with classroom routines.

\section{(3) Satisfying psychology needs}

Núñez and Téllez (2015) highlighted that RT helps teachers to become more positive and confident. Through RT, teachers discover their weaknesses and strengths in their practice and find the best way to deliver lessons, which leads to better teaching practice and students' outcomes. As a result, teachers build up their confidence as seeing the positive impact of changes on their performance and students' achievement. Regarding RT through collaborative activities, Dewert et al., (2003) claimed that RT through collaboration is an effective means of providing social, emotional, practical, and professional support for teachers. It encourages a non-threatening and supportive atmosphere where teachers could share, guide and support each other effectively. This pressure-free atmosphere helps teachers share their experiences and express themselves effortlessly. Therefore, they feel more encouraged, motivated and committed to the profession.

\section{(4) Developing the teaching profession}

Loughran (2002) suggested that reflection brings teachers the understanding of their context-specific pedagogy (or contextual knowledge) and the ability to make decisions 
on appropriately applying knowledge in their practice. Furthermore, teachers through reflection can develop new premises of practice which will foster new and improved instruction. Therefore, RT is the key feature for long-term professional development (Jones \& Ryan, 2014).

\section{Types of reflective teaching}

Schön (1991) divided reflection into two types and distinguished between "reflection-inaction" and "reflection-on-action" by expanding the theory of reflection generated by Dewey (1933).

Reflection-in-action, also known as active or interactive reflection, can be defined as conscious thinking and modification while practicing. Through this type of reflection, reflective practitioners can immediately reflect on the action upon confronting it per se. For this reason, this type of reflection can also be defined as a stop-and-think process in which a teacher virtually evaluates the situation and makes an immediate decision on it (Van Manen, 1991). Reflection-in-action helps teachers figure out the weaknesses or provides alternatives to unexpected problems at hand.

Reflection-on-action, as it can be concluded from the name itself, involves reflecting on how practice can be developed following previous lessons completed. The teacher attempts to see whether the activity/lesson is successful or not by making valid judgments on his own. Moreover, the teacher tries to see if there is an alternative to reach the same or better outcomes of the action (Marcos, 2009). Therefore, by analyzing the past, not only experiences but also active thinking processes in actions help reflective teachers enhance their teaching practice.

Reflection-for-action, as a pivotal contributor to reflective practice, has been initiated by Van Manen (1991), who argued that teachers not only use reflection to solve problems that happen at the time of teaching to contemplate the alternatives about past experiences, but also consider the possible problems or situations that they may confront in their future teaching.

\section{Strategies of reflective teaching}

Teachers can choose from various strategies/activities or approaches of how to apply RT practice, either individual/self-reflection or reflection with peers/partners. The following are the common ones (Cirocki \& Widodo, 2019; Nambiar \& Melor, 2017; Nguyen et al., 2015; Sinno, 2016):

(1) A teaching journal is a self-discovery process using diary devices, documenting feelings and facts surrounding an event, the steps involved, and important elements. Patterns and themes emerge to assist with future planning by analyzing and interpreting the writings.

(2) The portfolio is the collected samples of professional documents such as lesson plans, units of study, student work samples, teaching philosophy, achievements, etc., which reflect their knowledge, skills, and beliefs. Especially, e-portfolio helps create a sense of ownership and personalization as it allows teachers to document their reflections, assignments, reading materials and electronic teaching aids in their own desired way 
(3) Student feedback can be gathered via questionnaires, student conversations or telephone interviews. Teachers can ask their students what they are thinking about what goes on in the classroom. Students' opinions and perceptions can add a different and valuable perspective in teaching. Students are the direct recipients of instructions and constant contact with their teachers; therefore, student feedback is a valuable source for teachers to reflect upon and then improve their teaching practice.

(4) Action research is a process in which participants examine systematically and carefully their educational practices, using inquiry techniques. The process permits teachers to research and reflect on teaching to acquire knowledge and grow professionally.

(5) Video-recording of lessons can provide a valuable "reality check" for teachers. They can be replayed to examine different aspects or gain new insights into teaching. They provide important evidence to back up an observer's comments, and of a teacher's progress. Upon viewing them, teachers may feel the need to change their practice and are more likely to remember to implement change where there are dichotomies between their ideas about good teaching and what they have seen as constituting their actual practice.

(6) Peer-observation/coaching is used to study teaching, refine teaching practice, and encourage reflective practice, involving a continuous relationship with a partner founded on trust and openness. Each teacher in this approach has an opportunity to act as the coach because of their expertise in an area.

(7) A study group is a way to capture the art of teaching through professional reading, dialogue, and observation. Study groups consist of 6-10 teachers who meet frequently to discuss a common interest. Teachers investigate curricular, instructional, and assessment innovations to refine their knowledge and incorporate best practices into their teaching experience.

(8) Classroom walkthrough observation is when a supervisor visits and observes the happenings in the classroom. It provides channels for professional dialogues between the supervisor and in-charge teachers about instructional practices in the classroom.

(9) Workshops are used as short-term learning programs for in-service teachers to get knowledge of issues related to their teaching practice. Workshops entitle teachers to learn something from experts who share knowledge and experiences that they can later employ in their teaching practice. Besides, they also have opportunities to survey their beliefs or perspectives on teaching and learning and reflect on their teaching practice.

\section{Previous studies}

As mentioned above, on the one hand, a systematic, comprehensive investigation on the relevant issue has not been postulated in the context of Vietnam since RT is still a novel or underdeveloped construct among researchers in this country (Nguyen et al, 2015). On the other hand, quite a large volume of previous studies from other countries have been conducted in the field. Some recent studies are mentioned in this section (other ones can be found in the next sections). For example, the study in Indonesia by Tosriadi et al. (2018) showed that the EFL teachers partaking in the survey used teaching 
journal/reflective journaling, peer-observation, audio/video recording, and action research, but they did not utilize these strategies effectively due to their insufficient knowledge of RT. With regard to reflective journal, past research by Azizah et al. (2018), Cholifah et al. (2019), Zulfikar and Mujiburrahman (2018), etc., has confirmed its benefits on EFL teachers. Meanwhile, Maleki (2017) conducted an empirical study in Iran with an experimental group of $15 \mathrm{EFL}$ teachers who underwent a reflection course during 10 weeks and gained a significant progress in their self-efficacy. Likewise, the pre-service EFL teachers who participated in a 10-week workshop of reflective practice in Chile were found to develop confidence in their ability to problem-solve and become more aware of the need for teachers to change (Gutierrez et al., 2019).

Since RT is a complex process embedded in various teaching activities in the classroom and behind the classroom, past research in the field has examined it from different aspects and in dissimilar constructional contexts. Although previous studies have obtained remarkable findings, they have yet to be exhaustive or rigorously conclusive across the countries. As a result, more studies like the present one in Vietnam, where the construct of RT is still in its beginning stages of research, are necessary.

\section{METHOD}

\section{Research instruments}

A questionnaire and interview were employed as research instruments to collect data in this study. The questionnaire was used to collect the quantitative data to answer the research questions about teachers' perceptions and practices of RT. A well-designed questionnaire can provide keen insights into how participants think and perceive the situation (Bernard, 2000). Moreover, this is an effective and quick way to obtain a huge amount of information especially to a large number of respondents in a short time. However, a semi-structured interview was utilized in the current study as well to triangulate the data.

The questionnaire was displayed in four sections encompassing items/statements selected and somehow adapted from those used in the relevant literature. The first section of four demographic items is aimed to gain information about the subjects' gender, age, academic qualifications, and teaching experience. The second section (13 items) is presented on a 5-point scale ranging from "Strongly agree" to "Strongly disagree", seeking the subjects' perceptions on the benefits of RT. The third (9 items) and fourth section (10 items) are found in a 5-degree-frequency format from "Always" to "Almost never", assessing the subjects' frequencies of RT practice in terms of types and strategies.

Initial results from the questionnaire were used to develop themes for further investigation in the study's second phase, namely a semi-structured interview. The interview was considered as a tool to double-check the obtained results from the questionnaire regarding the subjects' perceptions of RT benefits and practices. More importantly, it was aimed to seek individual accounts for used and/or unused strategies, difficulties in RT practices. Thus, assigned interview questions are as follows:

(1) Have you ever reflected on your teaching? If yes, how often do you reflect? 
(2) When do you reflect on your teaching practice? (in/ on/for)

(3) What are some benefits you gain from reflection? Why do you think so?

(4) Have you ever used any reflective teaching tools such as dairy/journal, peerobservation, study-group, student-feedback, etc.?

(5) If yes, why do you opt for these activities? If no, why don't you use these activities?

(6) What are the challenging things/difficulties you face in reflective teaching?

\section{Participants}

\section{Participants for the questionnaire}

The criteria for selecting the studied setting and participants included the factors of convenience, access, and willingness of participants. Firstly, the chosen institution is within a practical distance as well as the participants expressed a desire to be in the study. This site was also selected because of the researcher's intense desire to give her colleagues opportunities to raise their awareness of the importance and benefits of RT; thereby possibly improving their RT practice.

A total of 49 teachers working at an English Language Centre in Can Tho City, South of Vietnam (13 males, $26.5 \%$ and 36 females, $73.5 \%$; ranging between 22 to 39 years old) were invited (by email and phone calls), and they all voluntarily agreed to take part in answering the questionnaires. As shown in Table 1, at the time of research most of the participants had been teaching English for more than two years; specifically, $51 \%$ of them had from 2-5 years, and 37\% more than five years of English teaching experience. However, $12 \%$ had been in the career for less than two years. In terms of academic qualifications, most of them have accomplished a Bachelor's Degree (80\%). The rest holds a Masters' Degree (20\%).

Table 1

Background information of participants for questionnaire

\begin{tabular}{llll}
\hline Background Information & & Frequency & Percentage (\%) \\
\hline \multirow{2}{*}{ Gender } & Male & 13 & 26.5 \\
\cline { 2 - 4 } & Female & 36 & 73.5 \\
\hline \multirow{2}{*}{ Age } & $23-29$ years old & 37 & 75.5 \\
\cline { 2 - 4 } & $30-39$ years old & 12 & 24.5 \\
\hline \multirow{2}{*}{ Teaching experience } & Less than two years & 6 & 12 \\
\cline { 2 - 4 } & From 2 to 5 years & 25 & 51 \\
\cline { 2 - 4 } & More than 5 years & 18 & 37 \\
\hline Academic qualifications & Bachelor & 39 & 80 \\
\cline { 2 - 3 } & Master & 10 & 20 \\
\hline
\end{tabular}

\section{Participants for interview}

To gain deep insights into the target issue, the researcher conducted interviews with six teacher participants who were invited and consented to partake in the interviews based on their responses in the prior questionnaire. The interviews were conducted with two groups of participants. Group I, the "more reflective" group with three participants, were selected from those whose responses were mostly "strongly agree" or "agree" (i.e. higher mean score); Group II, the "less reflective" group of three participants, was among those whose responses were mostly "strongly disagree" or "disagree" (i.e. lower mean score). Table 2 provides their background information. 
Table 2

Interviewees' background information

\begin{tabular}{lllllll}
\hline Groups & Interviewees & $\begin{array}{l}\text { Mean } \\
\text { score }\end{array}$ & Gender & Age & $\begin{array}{l}\text { Teaching } \\
\text { experience }\end{array}$ & $\begin{array}{l}\text { Academic } \\
\text { qualification }\end{array}$ \\
\hline \multirow{2}{*}{$\begin{array}{l}\text { I - "more } \\
\text { reflective" }\end{array}$} & Teacher A & 4.11 & Female & 30 & 8 years & Master \\
\cline { 2 - 6 } & Teacher B & 4.09 & Female & 26 & 4 years & Bachelor \\
\cline { 2 - 6 } & Teacher C & 4.0 & Male & 26 & 4 years & Bachelor \\
\hline \multirow{2}{*}{$\begin{array}{l}\text { II - "less } \\
\text { reflective" }\end{array}$} & Teacher D & 2.93 & Female & 30 & 7 years & Master \\
\cline { 2 - 6 } & Teacher E & 2.84 & Female & 38 & 16 years & Bachelor \\
\cline { 2 - 6 } & Teacher F & 2.0 & Female & 23 & 1.5 years & Bachelor \\
\hline
\end{tabular}

Data collection and analysis

After the first questionnaire version was designed, it was revised several times based on the experienced EFL teachers' comments and suggestions. It was piloted with twentynine teachers who shared a similar teaching context with target participants. The piloted questionnaire in Google Form was sent to the teachers via email. The data collected from the piloted questionnaire were run on the Statistical Package for the Social Science (SPSS version 20) to check the reliability of the instrument. The findings detected 28 valid cases and one invalid case from the data collected, and the reliability coefficient was relatively high $(\alpha=0.86)$. The results indicated that the questionnaire was reliable for the official questionnaire administration. The participants in the pilot study were excluded from the major research. Then, the official questionnaire was delivered to 49 participants via email on Google Forms. Two weeks later, all 49 questionnaire copies delivered were returned through Google Forms.

Following the questionnaire results, the interview was conducted with six participants placed in two groups, three of the "more reflective" group and the other three of the "less reflective". Then, the researcher contacted them via email and phone calls, explaining the purposes of the interviews as well as the confidentiality of the collected interview information and the anonymity of the interviewee. The place and time were pre-arranged in a way that was most convenient for the interviewees. The length of time for each interview ranged from 10-20 minutes. All of the interviews were conducted in Vietnamese and then translated into English by the researcher. Each participant was interviewed face-to-face, and all the responses were recorded and also taken notes carefully by the researcher with the permission of the participants. For the qualitative analysis, the written responses of the interviewees were analyzed.

The quantitative data collected from the questionnaire were coded into numbers and analyzed by the SPSS) software (Version 20). Firstly, the Scale Test was run to check the reliability of the questionnaire. Next, a descriptive Statistic Test was then calculated to observe the mean scores, the maximum, the minimum and standard deviations.

For the recorded qualitative data, basing on the recordings and the taken notes during the interviews, the researcher transcribed the interviewees' responses in Vietnamese to have a profound understanding of their thoughts. Then the transcriptions were re-read carefully and critically analyzed by the researcher. Whenever unclear understanding or ambiguity occurred, the researcher contacted the interviewees to ask for clarification. After that, the Vietnamese transcriptions were translated into English by the researcher 
and then sent back to the interviewees each for confirmations. Finally, the data were interpreted and analyzed with reference to the themes from the questionnaire results.

\section{Research schedule}

The whole study was conducted within 20 weeks (May - September 2019) as follows,

Table 3

Study schedule

\begin{tabular}{cllll}
\hline \multicolumn{2}{l}{ Research activities } & Instruments & Outcomes & Timeline \\
\hline 1. & Studying literature & & Literature review & Week 1-5 \\
\hline 2. & Designing the questionnaire & Questionnaire & Initial \& revised version & Week 6-8 \\
\hline 3. & Piloting questionnaire & Questionnaire & Feedback from colleagues & Week 9 \\
\cline { 3 - 5 } & & & Piloting results & Week 10 \\
\hline 4. & Delivering and collecting questionnaire & Questionnaire & Google forms collected & Week 11-12 \\
\hline 5. & Collecting data by interview & Interview & $\begin{array}{l}\text { Recording files and } \\
\text { transcription }\end{array}$ & Week 13-14 \\
\hline 6. & Analyzing and synthesizing data & SPSS 20 & Final results & Week 15-20 \\
\hline
\end{tabular}

\section{FINDINGS}

\section{Questionnaire results}

Data collected from the questionnaire was subjected to the SPSS software for data analysis. First, a Reliability Analysis was conducted to check the reliability of the questionnaire. The reliability coefficient of the questionnaire was high $(\alpha=0.89)$. The result shows that the questionnaire in the current study was reliable.

\section{Perceptions of reflective teaching benefits}

Table 4

Teachers' perceptions of RT benefits

\begin{tabular}{|c|c|c|c|c|c|c|c|}
\hline \multicolumn{2}{|c|}{$\begin{array}{l}\text { Section 3: } \\
\text { Items }\end{array}$} & \multirow{2}{*}{$\begin{array}{l}\begin{array}{l}\text { Mean } \\
\text { score }\end{array} \\
4.78 \\
\end{array}$} & \multirow{2}{*}{$\begin{array}{l}\text { Strongly } \\
\text { agree } \\
(\%) \\
77.6\end{array}$} & \multirow{2}{*}{$\begin{array}{l}\text { Agree } \\
(\%) \\
22.4\end{array}$} & \multirow{2}{*}{$\begin{array}{l}\text { Neutral } \\
(\%) \\
0.0\end{array}$} & \multirow{2}{*}{$\begin{array}{l}\text { Disagree } \\
(\%) \\
0.0\end{array}$} & \multirow{2}{*}{$\begin{array}{l}\text { Strongly } \\
\text { disagree } \\
(\%) \\
0.0 \\
\end{array}$} \\
\hline 1 & Professional development is necessary for EFL teachers. & & & & & & \\
\hline 2 & Professional development is a lifelong activity. & 4.71 & 75.5 & 20.4 & 4.1 & 0.0 & 0.0 \\
\hline 3 & $\begin{array}{l}\text { RT is a useful tool for EFL teacher to develop their } \\
\text { professional development }\end{array}$ & 4.41 & 51.0 & 40.8 & 6.1 & 2.0 & 0.0 \\
\hline 4 & RT raises teachers' awareness of their teaching practice. & 4.47 & 57.1 & 34.7 & 6.1 & 2.0 & 0.0 \\
\hline 5 & $\begin{array}{l}\text { RT helps teachers be well-prepared to deal with } \\
\text { unexpected teaching situations. }\end{array}$ & 4.24 & 42.9 & 40.8 & 14.3 & 2.0 & 0.0 \\
\hline 6 & RT helps teachers gain more teaching experience. & 4.61 & 63.3 & 34.7 & 2.0 & 0.0 & 0.0 \\
\hline 7 & $\begin{array}{l}\text { RT helps teachers deal with the present teaching } \\
\text { situation based on experience. }\end{array}$ & 3.90 & 22.4 & 44.9 & 32.7 & 0.0 & 0.0 \\
\hline 8 & $\begin{array}{l}\text { RT helps teachers choose the best way to deliver a } \\
\text { lesson. }\end{array}$ & 3.92 & 20.4 & 53.1 & 24.5 & 2.0 & 0.0 \\
\hline 9 & $\begin{array}{l}\text { RT helps teachers feel more confident in their teaching } \\
\text { practice. }\end{array}$ & 3.88 & 12.2 & 65.3 & 20.4 & 2.0 & 0.0 \\
\hline 10 & $\begin{array}{l}\text { RT provides teachers with emotional and professional } \\
\text { support from colleagues. }\end{array}$ & 3.65 & 8.2 & 53.1 & 34.7 & 4.1 & 0.0 \\
\hline 11 & $\begin{array}{l}\text { RT enhances teachers' autonomy and intrinsic } \\
\text { motivation. }\end{array}$ & 3.94 & 24.5 & 49.0 & 24.5 & 0.0 & 2.0 \\
\hline 12 & $\begin{array}{l}\text { RT brings teachers a better understanding of their } \\
\text { context-specific pedagogy. }\end{array}$ & 3.90 & 20.4 & 53.1 & 24.5 & 0.0 & 2.0 \\
\hline 13 & RT fosters new and improved teaching practices. & 4.27 & 42.9 & 44.9 & 10.2 & 0.0 & 2.0 \\
\hline
\end{tabular}

Average Mean $=4.21$ 
Section 1 in the questionnaire investigated the surveyed teachers' perceptions on RT. As presented in table 4 , it can be seen that the average mean $M=4.21$ out of 5 is a high mean score. Significantly, what stands out from the table is that all the respondents agreed that professional development is necessary for EFL teachers (Item 1, 77.6\% strongly agree and $22.4 \%$ agree). Also, more than $95 \%$ agreed that professional development is a lifelong activity (Item 2, 75.5\% strongly agree and $20.4 \%$ agree). In the same line, RT was highly perceived as a useful tool for EFL teacher professional development (Item 3, M=4.41), for raising awareness of teaching practice (Item 4, $\mathrm{M}=4.47$ ), helping be well-prepared dealing with unexpected situations (Item 5, $\mathrm{M}=4.24$ ), gaining more teaching experience (Item 6, M=4.61), and fostering new and improved teaching practice (Item 13, M=4.27).

\section{Practice of reflection-in-action, on-action and for-action}

Table 5

Teachers' practice of three types of RT

\begin{tabular}{|c|c|c|c|c|c|c|c|}
\hline \multicolumn{2}{|c|}{$\begin{array}{l}\text { Section 3: } \\
\text { Items }\end{array}$} & \multirow{2}{*}{$\begin{array}{l}\begin{array}{l}\text { Mean } \\
\text { score }\end{array} \\
3.86\end{array}$} & \multirow{2}{*}{$\begin{array}{l}(\%) \\
\text { Always } \\
14.3\end{array}$} & \multirow{2}{*}{$\begin{array}{l}\text { Usually } \\
(\%) \\
61.2\end{array}$} & \multirow{2}{*}{$\begin{array}{l}\begin{array}{l}\text { Some- } \\
\text { times } \\
(\%)\end{array} \\
20.4\end{array}$} & \multirow{2}{*}{$\begin{array}{l}\text { Rarely } \\
(\%) \\
4.1\end{array}$} & \multirow{2}{*}{$\begin{array}{l}\text { Almost } \\
\text { never } \\
(\%)\end{array}$} \\
\hline $\begin{array}{l}1 \\
4\end{array}$ & $\begin{array}{l}\text { I can quickly react to teaching } \\
\text { problems happening in class. }\end{array}$ & & & & & & \\
\hline $\begin{array}{l}1 \\
5\end{array}$ & $\begin{array}{l}\text { I notice students' attitudes during the } \\
\text { teaching process. }\end{array}$ & 4.45 & 57.1 & 36.7 & 2.0 & 2.0 & 2.0 \\
\hline $\begin{array}{l}1 \\
6\end{array}$ & $\begin{array}{l}\text { I adjust my instruction or activities } \\
\text { based on students' attitudes in class. }\end{array}$ & 4.22 & 28.6 & 69.4 & 0.0 & 0.0 & 2.0 \\
\hline $\begin{array}{l}1 \\
7\end{array}$ & $\begin{array}{l}\text { I try to understand my purposes, } \\
\text { intentions, and feeling in any teaching } \\
\text { activities }\end{array}$ & 4.37 & 51.0 & 38.8 & 8.2 & 0.0 & 2.0 \\
\hline $\begin{array}{l}1 \\
8\end{array}$ & $\begin{array}{l}\text { Before class, I plan the lesson and } \\
\text { anticipate what may happen and try to } \\
\text { find a solution for that. }\end{array}$ & 4.35 & 46.9 & 44.9 & 6.1 & 0.0 & 2.0 \\
\hline $\begin{array}{l}1 \\
9 \\
\end{array}$ & $\begin{array}{l}\text { After class, I look back on what } \\
\text { happened in class. }\end{array}$ & 4.02 & 24.5 & 57.1 & 14.3 & 4.1 & 0.0 \\
\hline $\begin{array}{l}2 \\
0\end{array}$ & $\begin{array}{l}\text { After class, I try to find out the reasons } \\
\text { for teaching problems in the previous } \\
\text { lesson. }\end{array}$ & 4.16 & 34.7 & 53.1 & 6.1 & 6.1 & 0.0 \\
\hline $\begin{array}{l}2 \\
1\end{array}$ & $\begin{array}{l}\text { I analyze my teaching activities based } \\
\text { on the objectives of my lessons to } \\
\text { make some changes in the future. }\end{array}$ & 4.12 & 30.6 & 57.1 & 6.1 & 6.1 & 0.0 \\
\hline $\begin{array}{l}2 \\
2\end{array}$ & $\begin{array}{l}\text { I can figure out teaching problems } \\
\text { happening in class. }\end{array}$ & 3.96 & 22.4 & 55.1 & 18.4 & 4.1 & 0.0 \\
\hline
\end{tabular}

Average Mean $=4.16$

With the average mean 4.16 (out of 5 ) as seen in table 5 , the results show that all three RT types (in-, on-, and for-action) were more or less practiced by the surveyed teachers. Most of the items gained above 4.00, indicating that these practices were performed regularly. Topping the list is Item $15(\mathrm{M}=4.45)$, implying that the teachers attended closely to the learner's feelings or reactions during the lesson so that they could adjust ongoing activities/instruction (Item 16) or figure out possible problems arising in class (Item 23), and quickly treating them (Item 14). Also, they did usually practice reflection-on-action (Item 17, 18, 19) and reflection-for-action $(21,22)$. 


\section{Practiced strategies of reflective teaching}

Table 6

Teachers' practice of RT strategies

\begin{tabular}{|c|c|c|c|c|c|c|c|}
\hline & $\begin{array}{l}\text { Section 4: } \\
\text { Items }\end{array}$ & $\begin{array}{l}\text { Mean } \\
\text { score }\end{array}$ & $\begin{array}{l}(\%) \\
\text { Always }\end{array}$ & $\begin{array}{l}\text { Usually } \\
(\%)\end{array}$ & $\begin{array}{l}\text { Some- } \\
\text { times } \\
(\%)\end{array}$ & $\begin{array}{l}\text { Rarely } \\
(\%)\end{array}$ & $\begin{array}{l}\text { Almost } \\
\text { never } \\
(\%)\end{array}$ \\
\hline 23 & $\begin{array}{l}\text { I document my teaching experience using } \\
\text { a reflective journal. }\end{array}$ & 1.92 & 2.0 & 10.2 & 16.3 & 20.4 & 51.0 \\
\hline 24 & $\begin{array}{l}\text { I record videos or audios of my teaching } \\
\text { practice and reflect upon them. }\end{array}$ & 1.76 & 0.0 & 2.0 & 14.3 & 40.8 & 42.9 \\
\hline 25 & $\begin{array}{l}\text { I collect a teaching portfolio to reflect on } \\
\text { my teaching. }\end{array}$ & 1.94 & 2.0 & 4.1 & 20.4 & 32.7 & 40.8 \\
\hline 26 & $\begin{array}{l}\text { I research repeated teaching issues to } \\
\text { reflect my teaching practice. }\end{array}$ & 2.35 & 0.0 & 22.4 & 10.2 & 46.9 & 20.4 \\
\hline 27 & $\begin{array}{l}\text { I use peer observation to reflect on my } \\
\text { teaching practice. }\end{array}$ & 2.78 & 2.0 & 24.5 & 26.5 & 42.9 & 4.1 \\
\hline 28 & $\begin{array}{l}\text { I and my colleagues work together to have } \\
\text { an observation and reflect on each other } \\
\text { teaching. }\end{array}$ & 2.73 & 2.0 & 16.3 & 44.9 & 26.5 & 10.2 \\
\hline 29 & $\begin{array}{l}\text { I join a study-group with other teachers } \\
\text { where we discuss on our lesson plan, have } \\
\text { an observation and reflect on our teaching }\end{array}$ & 2.73 & 2.0 & 20.4 & 34.7 & 34.7 & 8.2 \\
\hline 30 & $\begin{array}{l}\text { The supervisor in my school visit } \\
\text { classrooms to observe and give feedback. } \\
\text { I reflect on my teaching based on their } \\
\text { feedback. }\end{array}$ & 3.24 & 2.0 & 53.1 & 18.4 & 20.4 & 6.1 \\
\hline 31 & $\begin{array}{l}\text { I attend teaching workshops and reflect on } \\
\text { my teaching practice based on them. }\end{array}$ & 4.10 & 34.7 & 42.9 & 20.4 & 2.0 & 0.0 \\
\hline 32 & $\begin{array}{l}\text { I collect students' feedback and reflect } \\
\text { upon them. }\end{array}$ & 3.59 & 16.3 & 51.0 & 12.2 & 16.3 & 4.1 \\
\hline
\end{tabular}

Average Mean $=2.71$

What stands out in table 6 above is that attending workshops was most often utilized by the teachers (Item 31, M=4.10). This is followed by collecting student feedback and having the supervisor observing and giving comments (Item 32, M=3.59 and Item 30, $\mathrm{M}=3.24$, respectively). On the contrary, other forms of individual reflection were rarely applied, especially collecting portfolios (Item 24), writing reflective journals (Item 23) or recording videos/audios of teaching practice (Item 25).

\section{Interview results}

\section{Perceived benefits of reflective teaching}

All six interviewed teachers did acknowledge the benefits of RT, which correlated with the four remarkable benefits (with the highest mean scores, Table 4) in the questionnaire results, namely teaching experience, awareness of teaching practice, dealing with unexpected teaching situations and fostering new and improved teaching practice. They said:

I can be more experienced in teaching based on RT. I can be more flexible in applying strategies for different classes and students. I mean when applying RT, I don't have to follow exactly what has been planned but can adjust my teaching method according to teaching purposes. (Teacher B) 
First of all, RT helps me get more experience... When teaching old lessons again, I know how to teach them effectively because I have already taught and reflected on these lessons before. From the experiment and reflection of different teaching methods, I can flexibly and efficiently apply these methods for future lessons. (Teacher C)

In some cases, the informants reported that RT raises their awareness of their teaching practice. They recognized their strengths and weaknesses through reflection process so that they can improve themselves and their performance, and that affects students learning as well, for example:

When I feel unsatisfied with the lesson results, I need to reflect to look for the reasons to enhance better teaching in the future. (Teacher D)

$R T$ helps me acknowledge myself so that I can improve my teaching practice... and I can support my students' learning. (Teacher E)

As the teachers discussed, it became clear that they viewed RT as the key for selfassessment. Thanks to the awareness of their teaching, teachers access themselves so that they can improve their professional development, and therefore enhance students learning. On dealing with unexpected teaching situations, two of them claimed that,

Besides, RT contributes to better reactions to unexpected situations. When confronting such situations, I can recall similar situations and reflections in the past to search for the best solutions. (Teacher B)

If I faced a problem that I already had in the past, I will try to recall my old reflection to solve the problem better...I hope that as I practice RT more and get more experiences, I can be better at solving such situations. (Teacher F)

It can be derived from the teachers' responses that RT facilitates teachers in dealing with unexpected teaching situations. Since they practice RT, in addition to gaining more teaching experiences, teachers can properly handle accidental incidents in the classroom.

Finally, there is a consensus among the interviewees that RT fosters new and improved teaching practices; therefore, it results in teacher growth and students' outcomes. As illustrated in some responses of the participants below,

RT makes progress in my teaching practice. I think that, more or less, my teaching performance is better than before; and therefore, my students can study more effectively. (Teacher A)

I can improve my teaching practice, in both methods and content quality. I can deliver more interesting lessons that promote students' learning and outcomes. (Teacher E)

Thus, thanks to RT implementation, the teachers gradually acquired better teaching methods, better problem-solving strategies, and also sensed learning outcomes among students. All these together mostly entitle them to feel more confident in their career. It can be exemplified in the responses below, 
RT enhances my confidence when teaching because I know what technique is effective and what is not. (Teacher A)

I feel more confident before lessons because I already planned and reflected on them. (Teacher C)

I feel more confident about my teaching practice. And, I also feel confident in handling unexpected situations. (Teacher F)

Overall, findings from the interview suggest that both "more reflective" and "less reflective" groups enjoyed the benefits of RT. As a result, these results mostly match those findings from the questionnaire survey in which the teachers highlighted the benefits of RT in promoting teaching experiences, raising awareness of teaching practice, enhancing better reaction to problematic situations in class and suggesting the most effective teaching methods. Especially, most interviewees also emphasize the role of RT in promoting their confidence in different aspects of their teaching career.

\section{The practice of reflection-in-action, on-action, and for-action}

The results from the interviews illustrated that all teachers practiced RT frequently but biased towards different types of RT. The teachers from the "more reflective" group/Group I revealed that they reflected on every class and lesson. On the other hand, the teachers from the "less reflective" group/Group II stated that they always reflected before class and when there were cases or problematic situations. They said,

I practice all three types of RT (in, on and for). (Teacher A - Group I)

I think every teacher, more or less, has reflected on their teaching. To me, I usually reflect on every lesson. (Teacher B - Group I)

I usually reflect on my teaching when there are unexpected situations that make me confused. (Teacher E - Group II)

Moreover, Group-II teachers seemed to focus on reflection-for-action and disregarded the other two types. They spent time recalling their teaching experiences, reflecting on them, and planning the lesson before class. They did reflect in class but very little. Their reflection-in-action and reflection-for-action normally stopped at thinking about the effectiveness of lessons, and they made little effort on detecting reasons for problems arising or searching for solutions.

I usually reflect before class to plan for new lessons. Of course, when I faced problems in class or my lesson failed, I kept thinking about that. I just thought about that but did nothing because, to tell the truth, I don't have time to deeply reflect on my lessons. I just try to spare my time planning my lesson before class. (Teacher D)

Normally, I reflect on my teaching before class so that I can plan for new lessons. And, when I face problems in class, I solve them immediately. I react to problems intuitively because they emerge unexpectedly so I don't have time for reflection. I rarely reflect after class because I have finished the lesson and nothing can be changed. (Teacher F) 
On the contrary, Group-I teachers regularly practiced all three types of RT. Noticeably, two of them put more concerns in reflection-on-action. They explained that they had more time for reflection and that they still remembered clearly their teaching performances. Through their responses, it is undoubtedly that the Group-I teachers were deeper and more effective in reflecting on their teaching. They also viewed their teaching under various perspectives and tried to find the best solutions. Teacher A reported,

After class, at home, I usually spend 15-30 minutes to reflect on my lesson because I still remember clearly. I usually deal with problematic situations right away in class such as slowing down my teaching or re-teaching the contents. And, after class, I also look back and reflect on whether my solutions are appropriate, and sought more effective solutions....After getting to know my new class's characteristics, before class, I adjust my lesson plan to suit them ... an hour before class...I usually find a quiet place to look through my lesson plan and try to anticipate some questions that students may ask during class...I think teachers should spend time on reflection-on-action so I spend much time on this type of RT. I think it is very useful for teachers if we can practice it as a habit.

Together, these findings provide important insights into teachers' practice of RT. The results were in correlation to what was explored from the questionnaire that teachers frequently practice the three types of RT. The qualitative data, however, also signified differences in the practice of RT between the two groups of participants (the "more reflective" and "less reflective" groups).

\section{The practice of reflective teaching strategies}

The findings from the interview support the results of the survey that teachers utilized just some major tools in RT. First of all, attending workshops appeared to be the most used strategy. Corresponding with questionnaire data, all participants reported that they had ever attended a workshop for RT. Some of them confessed,

Moreover, I also attend workshops frequently to learn new teaching methods, to elevate my teaching effectiveness, and renovate instruction methods, strategies. (Teacher C)

I attended workshops to learn new teaching theories and new teaching methods. Sometimes, after attending the workshop I can realize the weak point in my teaching. Then I can improve my teaching based on what I learn from the workshop and apply new strategies to my teaching practice. (Teacher F)

However, despite its convenience and easy-accessibility, the workshop is reported to be fragmented or not conducive to the continuous process; sometimes not relevant and far from teachers' actual needs. As teacher D said, "Sometimes the workshop contents were not correlated to my real professional need."

Secondly, student feedback, either in verbal or written form, was also widely used among the teachers. Some viewed verbal feedback as a basis for their teaching adjustment right in the course of lesson procedure, which is considered reflection-inaction. Some even collected written feedback to plan their lessons subject to their 
students' needs and English proficiency level. Teacher B and F showed much concern towards student feedback, and picked up the most from it as seen below:

Then I will base on this feedback to plan coming lessons suitable to their interests. I sometimes asked for student feedback after class. I ask myself if students need any change for better learning and having more fun in class. I ask questions about what they have learned and feedback for me so that I can make necessary changes in the future. (Teacher B)

I think collect student feedback is the most effective tool because the teaching method directly affects student learning. Therefore, if they have negative feedback about teaching methods, we need to reflect on our teaching more. (Teacher F)

Thirdly, as findings from the questionnaire indicated that classroom walk-through observation was among the three strategies mostly employed (Table 6, Item 30, $\mathrm{M}=3.24)$. However, this tool seemed not to be a self-regulated strategy as all interview participants confessed that it was a compulsory task required by the institution and that they did not always agree on the supervisors' feedback afterward,

The supervisors sometimes observe and give me feedback to reflect on...that classroom walk-through is a requirement from the institution...the supervisors do not clearly understand my students and classroom characteristics so they sometimes give irrelevant feedback. (Teacher E)

Apart from student feedback, workshop, and class walk-through observation, other strategies were confirmed to be rarely used by the teachers due to difficulties relating to time constraints and lack of RT knowledge and teachers' effort. Two out of six teachers claimed that they used to employ peer-feedback, but it was not regular because of different teaching schedules among the colleagues.

Significantly, the score result from the questionnaire matched that found in the interview in the case of Teacher A. She gained the highest mean score, and the interview discovered that she did utilize almost all the strategies listed in the questionnaire. She used to collect her teaching portfolio, which fostered her to deeply reflect, but it took up a lot of her time and effort. Recently, along with the three most used tools, she kept lesson-notes after class (a self-evaluation on teaching). She explained that the lessonnotes were useful for her reflection-in-action, reflection-on-action, and reflection-foraction as well.

\section{Difficulties in implementation of reflective teaching}

Although they appeared to more or less appreciate RT, teachers did acknowledge its challenges and expressed several reservations. They asserted that time constraint and overwork load was the biggest barrier to their RT. The teachers spared little time for RT because of the different jobs they had and the overload of stuff they had to do preparations for consecutive lessons for the entire semester all year round. Some confessed that there was not enough time being provided for deeper reflections, especially after busy long days of working and fatigue although they knew it was very 
helpful for professional development and they should invest more effort on RT. Five out of six teachers interviewed shared their reservations:

Sometimes I was too busy with other pieces of stuff, I cannot afford enough time for $R T$... (Teacher A)

To tell the truth, I don't have time to deeply reflect on my lesson. I just try to spare my time planning lessons ahead of class. I've been teaching many different classes, so I just have enough time for lesson planning only...I think RT requires a lot of time and effort, but I cannot invest much of my time and effort on it... (Teacher D)

I think the biggest difficulty for me is time. I think teachers must put much effort into maintaining RT, but it is too hard to do. (Teacher E)

Another reported problem was a lack of motivation or encouragement to practice RT. Some said they felt bored after a long time practicing and some did not have a feeling of commitment towards RT. These are evidenced in their genuine accounts:

When you do something for a long time, you will get bored of it. I have practiced RT for a long time... I find myself losing such an enlightening motivation for RT because I think that I can remember my old reflection on such issues in teaching and there is no need for reflection again. (Teacher A)

There were such times when I didn't want to reflect on my lesson anymore because I can't find solutions for my teaching problems, and sometimes I'm not sure if my solutions are reasonable and effective. There is no theoretical framework for me to base on and account for my solutions. Despite my clear awareness of its benefits for my instructions and students, I find myself sometimes neglect my RT... (Teacher B)

Even though she was one of the teachers who practiced RT on a very regular basis, Teacher B seemed to be confused about her practice and the effectiveness of RT. This insufficient knowledge of what and how to perform RT, and its tangible benefits is added by another teacher:

Currently, I don't know much about RT and I'm not sure how to practice and what tool is the best for RT. In short, I still cannot clearly perceive the concept of RT. (Teacher F)

\section{DISCUSSION}

As mentioned earlier, the current study was aimed to seek answers to three specific questions: (1) What are the surveyed teachers' perceptions of RT? (2) How often and what strategies do these EFL teachers practice RT? (3) Do they face any difficulties in $R T$ ? The following section discusses the obtained answers from the two data collection instruments employed in this study, namely questionnaire (quantitative) and interview (qualitative).

Firstly, virtually all the surveyed teachers acknowledged the benefits of RT because it was deemed a useful tool for EFL teachers' professional development by raising the awareness of teaching practice, helping identify their strengths and weaknesses, get well-prepared dealing with unexpected situations/incidents/events in the classroom, gain 
more teaching experiences, and thereby refine their instructions for the sakes of student learning outcomes. Added to these professional-related benefits, RT positively affected the teachers' psychology, increasing their confidence and motivation in job performances. In other words, the teachers showed their perceived understandings and appreciations of the RT significance. This is evidenced by both quantitative (questionnaire) and qualitative (interview) data in the current study conducted in the present EFL instructional context in Vietnam. This principal finding positively reflects those results reported in previous studies regarding in-/pre-service teachers' perceptions of RT and its beneficial impacts across different education settings of the EFL field around the world. These include Dumlao and Pinatacan (2019) in Thailand; Gutierrez et al. (2019) in Chile; Gungor (2016) in Turkey; Li (2008) in China; Minott (2011) in Cayman Islands; Tosriadi et al. (2018) in Indonesia; etc. In general terms, these results are gratifying because reflection is undoubtedly the heart of every professional activity in teaching career (Lubis, 2018), and it is "the central matter in the learning process and it can be described as a pendulation between phenomenon/situation-understandingconclusion/action" (Arnesson \& Albinsson, 2019, p.448). Besides, research has proved that reflective teachers are likely to be self-efficacious, who tend to "plan more effective lessons, persist when students face challenges, and search extensively for appropriate strategies and materials to improve student achievement" (Baleghizadeh \& Javidanmehr, 2014, p.30). In the same line, reviewing the relevant studies on RT published between 2009 - 2016, Garzon et al. (2018) concluded that "Studies in Colombia, England, Africa, Russia, and Turkey figured out that pedagogical reflection enhances in-service teachers' awareness about their function as teachers. Furthermore, they enrich constantly their teaching process and self-knowledge through reflection. As a result, they get more confident." (p.67)

Secondly, the current study also finds that although all three types of reflection (in-, on-, and for-action), as seen in Table 5 (average mean=4.16), gained high scores of practice frequency, only three strategies (workshop, student feedback, classroom walkthrough observation) were often exercised, while the rest were sometimes or rarely employed (Table 6, average mean=2.71). This finding is supported by the interview data. Of the three often used, workshop and student feedback appeared to gain the most attention from the surveyed teachers, and provide the most motivations for them. Unfortunately, classroom walkthrough observation, though compulsory in the country's educational system, was not enjoyed as optimally as the other two. This finding appropriately displays the common trend among EFL teachers in the current context of Vietnam, where professional workshops and training programs are frequently organized by the authorities (Truong, 2017), especially those workshops and courses inherent in the National Foreign Languages Project, 2008-2020 (MOET, 2008/2017). This finding, however, is not in line with those results found in many previous studies. In Gungor's action research (2016), of the three focused strategies (diaries, video-recorded microteaching, and lesson plans), diaries and video-recordings were found to benefit the participants best, enabling them to increase reflective thinkings, make decisions on relevant teaching techniques, prepare effective lessons, etc. Similarly, Dumlao and Pinatacan (2019) found that reflective journaling was an encouraging tool for pre- 
service EFL teachers to boost their critical thinkings, monitor, and evaluate teaching and learning practices. Likewise, in their investigation among in-service English teachers, Zulfikar and Mujiburrahman (2018) indicated that most in-service teachers regard reflective journals as an effective tool to increase teaching awareness, and thus improve their performance during teaching. Other studies revealing that reflective journaling is maximally practiced by in-service teachers include Azizah et al. (2018), Cholifah et al. (2019), and Sino (2016). Thus, reflective journaling or diary-writing is a priority strategy practiced by EFL teachers in many countries, but a workshop/training program is the case in the current study. One possible account for it is that attending these events, teachers are substantively assisted in deliberate reflections by professionals/teacher trainers (Cirocki \& Widodo, 2019; Li, 2005; Truong, 2017), especially for novice teachers feeling somehow at a loss for RT performances.

Thirdly, another important contribution from the current study is that although they perceived the values of RT quite well, most of the teachers found it uneasy to practice reflection optimally and frequently. This might account for a low average mean score $(=2.71)$ as seen in Table 6 above, and then three major constraints were unpacked from the interview results. First, productive reflection is time-consuming and great effortmaking, while daily overload work usually resulted in the teachers' fatigue by the end of the day. Lack of motivation for reflection was another challenge for them, and limited knowledge of what and how to reflect productively, especially among novice practitioners (Teacher F, for example, with just 1.5 years' teaching experience, Table 2), was the third constraint. This is understandable because reflectivity leads to professional growth, which is a lifelong process and obtaining initial certification and basic techniques is only a first step in this process $(\mathrm{Li}, 2008)$. As a consequence, continuing professional workshops/training programs are by all means beneficial for in-service teachers. During these events, under systematic, holistic guidances by qualified trainers, teachers are provided opportunity to look back on their past authentic instructional situations/actions/instances accumulated over time, reflecting more deeply, selfevaluating critically, and thereby possibly making reasonable changes in prospective instructions based on better-acquired knowledge of relevant theories/frameworks. Thanks to these deliberate, intensive reflections, they are supposed to make full sense of RT, and its significant impacts on professional development afterward. Concerning the third constraint, in a recent investigation by Azizah et al. (2018), one case of teacher shortage of time for reflective journaling should be referred to. This teacher did share her ways dealing with the constraint, which was reported by the authors (i.e. Azizah et al., 2018, p.6): "writing an important problem in the form of keywords as the key to remind what should be fixed in her teaching was the efficient strategies in order to break the limited time. Another way was recording or video-recording the whole activity in class so that the teacher could play the video or audio after class and wrote down challenges confronted in teaching. While remembering what had happened during the activity, the teacher might reflect and think critically those problems". Thus, it shows that as long as teachers hold genuine commitments to RT, and focal considerations with whole-hearted patience and responsibility, time shortage or workload-induced fatigue seem not to be an inherent barrier in the long run. 


\section{CONCLUSION}

The current study revisited the construct of RT, one of the indispensable components for professional development, which has widely been researched for the past decades around the world. It aimed to look at how this construct was perceived and practiced by a local group of EFL teachers in Vietnam's current context, where English is the major foreign language taught at all levels of education throughout the country, but related research on RT is still rare in this country. The obtained results show that the construct was quite well perceived in terms of its values, but was not optimally practiced by the surveyed teachers, who mostly attended to workshop/training program, student feedback, and classroom walkthrough observation. Meanwhile, other strategies of RT, (such as journaling/diary-writing, portfolio, and video-recording, which have been found frequently and productively implemented in many other countries) were seldom utilized mostly due to workload-induced time constraints, fatigue, and limited knowledge of RT. The focal implication from this study is that EFL teachers generally need some kind of continual professional training through workshops and short courses, for instance, which should purposefully encompass a deep theme of RT or feature an emphasis on it, exploring a wide repertoire of RT strategies. Furthermore, this theme should be one of the core components of the practicum session for pre-service EFL teachers.

The findings from the current study, however, should not be widely generalized to other places in the country owing to its limited participant sample with non-empirical evidence. Thus, to overcome this limitation, further inquiries in the field should involve larger samples, and ample empirical data via classroom observations, for example, to find out in actual practices how participants run lessons, and if they make any tangible evolving shifts resulting from reflecting on prior classroom incidents/events, possibly followed by their rational accounts for these shifts. Other investigations can look at measuring the levels of RT or detailed contents/aspects of reflection strategies in use.

\section{REFERENCES}

Arnesson, K. \& Albinsson, G. (2019) Reflecting talks: a pedagogical model in the learning organization. Reflective Practice, 20(4), 437-452. DOI: http://dx.doi.org/10.1080/14623943.2019.1638243

Azizah, U. A., Nurkamto, J., Drajati, N. A. \& Tosriadi, T. (2018). In-service English teacher's perceptions of reflective teacher diary to promote professional development. International Journal of Multicultural and Multireligious Understanding, 5(2), 1-8.

Baleghizadeh, S. \& Javidanmehr, Z. (2014). Exploring teachers' reflectivity and their sense of self-efficacy. E-International Journal of Educational Research, 5(3), 19-38.

Bernard, H. (2000). Social research methods: Qualitative and quantitative approaches. Thousand Oaks, California: Sage Publications.

Cholifah, A. N., Asib, A. \& Suparno (2019). Investigating in-service teacher's perception of practicing reflective teaching in the classroom: a case study of in-service EFL teachers in one of the senior high schools in Kartasura. iNELTAL Conference 
Proceedings: The International English Language Teachers and Lecturers Conference, 19-25.

Cirocki, A. \& Widodo, H. P. (2019). Reflective practice in English language teaching in Indonesia: Shared practices from two teacher educators. Iranian Journal of Language Teaching Research, 7(3), 15-35.

Dewert, M. H., Babinski, L. M. \& Jones, B. D. (2003). Safe passages: Providing online support to beginning teachers. Journal of Teacher Education, 54(4), 311-320.

Dewey, J. (1933). How we think: A restatement of the relation of reflective thinking to the educative process. Boston: DC Heath and Co. Publishers.

Dumlao, R. P. \& Pinatacan, J. R. (2019). From practice to writing: Using reflective journal instruction in enhancing pre-service teachers' professional development. International Journal of Instruction, 12(4), 459-478. DOI: http://dx.doi.org/10.29333/iji.2019.12430a

Ferraro, J. M. (2000). Reflective practice and professional development. ERIC Digest.

Garzon, A. A., Isaza, A. R. \& Munoz, D. M. (2018). Impact of pedagogical reflection in the teaching practicum from Caquetá practitioners' perspectives: a literature review. $\begin{array}{lllll}\text { Educación } y & \text { Humanismo, } & \text { 20(35), } & \text { 57-73. } & \text { DOI: }\end{array}$ http://dx.doi.org/10.17081/eduhum.20.35.2658

Gungor, M. N. (2016). Turkish pre-service teachers' reflective practices in teaching English to young learners. Australian Journal of Teacher Education, 41(2), 137-151. DOI: http://dx.doi.org/10.14221/ajte.2016v41n2.9

Gutierrez, M., Adasme, M. \& Westmacott, A. (2019). Collaborative reflective practice: Its influence on pre-service EFL teachers' emerging professional identities. Iranian Journal of Language Teaching Research, 7(3), 53-70.

Jones, M. \& Ryan, J. (2014). Learning in the practicum: Engaging pre-service teachers in reflective practice in the online space. Asia-Pacific Journal of Teacher Education, 42(2), 132-146.

Li, Hua (2008). Assessing EFL teachers' reflective thinking: a case study of two inservice secondary school teachers. Trends in Applied Sciences Research, 3(1), 36-44.

Loughran, J. J. (2002). Effective reflective practice: In search of meaning in learning about teaching. Journal of Teacher Education, 53(1), 33-43.

Lubis, A. H. (2018). Reflective teaching toward EFL teachers' autonomy: Revisiting its development in Indonesia. International Journal of Education, 11(1), 35-49. DOI: http://dx.doi.org/10.17509/ije.v11i1.9400

Maleki, M. (2017). On the impact of an EFL reflective practicum on teachers' selfefficacy. Journal of Applied Linguistics and Language Research, 4(4), 161-174. 
Marcos, J. J. M., Miguel, E. S. \& Tillema, H. (2009). Teacher reflection on action: What is said (in research) and what is done (in teaching). Reflective Practice, 10(2), 191-204. DOI: 10.1080/14623940902786206

MOET. (2008, 2017). Decision No. 1400/QĐ-TTg - 2080/QĐ-TTg: Teaching and learning foreign languages in the National Education System, period 2008 to 2020; and period 2017-2015 (Vietnam). Available from http://www.chinhphu.vn/portal/page/portal/chinhphu/hethongvanban. Accessed 26/04/2018.

Minott, M. A. (2011). The impact of a course in reflective teaching on student teachers at a local university college. Canadian Journal of Education, 34(2), 131-147.

Nambiar, K. \& Melor, Y. (2017). Reflective practice with e-portfolio. Malaysian Journal of ELT Research, 13(1), 43-54.

Nguyen, N., Trinh, L., \& Vo, B. (2015). Reflection - an effective means of teachers' professional development. Journal of Science, Can Tho University, 41(C),97-101.

Nguyen, N., Vo, B., Nguyen, T., \& Nguyen, Y. (2018). Professional development: Reflective stories of teacher educators at the School of Education, Can Tho University, Vietnam. DEPISA Monograph: Developing Educational Professionals in Southeast Asia, 5, 41-57.

Núñez Pardo, A., \& Téllez Téllez, M. F. (2015). Reflection on teachers' personal and professional growth through a materials development seminar. How, 22(2), 5474. http://dx.doi.org/10.19183/how.22.2.151.

Pollard, A., Black-Hawkins, K., Cliff-Hodges, G., Dudley, P., \& James, M. (2014). Reflective teaching in schools: Evidence-informed professional practice. Bloomsbury Publishing.

Postholm, M. B. (2008). Teachers developing practice: Reflection as a key activity. Teaching and Teacher Education, 24(7), 1717-1728.

Qing, X. (2009). Reflective teaching - an effective path for EFL teacher ${ }^{\text {re }}$ s professional development. Canadian Social Science, 5(2), 35-40.

Richards, J. C. (1995). Towards reflective teaching. English Teachers Journal (Israel), 59-63.

Schön, D. (1991) The reflective practitioner. Aldershot: Ashgate Publishing Ltd.

Sinno, C. (2016). Reflective teaching: impact, supports, and barriers from UAE-based ESL teachers' perspectives. Unpublished MA thesis. The American University of Sharjah, UAE.

Tosriadi, Asib, A., Marmanto, S. (2018). In-service EFL teachers' experiences of conducting reflective practice as continuing professional development. International Journal of Language Education, 2(2), 52-64. 
Truong, V. (2017). In search of effective professional development of EFL teachers in Vietnam. VNU Journal of Foreign Studies, 33(3), 157-166.

Van Manen, M. (1991). Reflectivity and the pedagogical moment: The normativity of pedagogical thinking and acting. Journal of Curriculum Studies, 23(6), 507-536. DOI: https://doi.org/10.1080/0022027910230602

Vazir, N. (2006). Reflection in action: Constructing narratives of experience. Reflective Practice, 7(4), 445-454. DOI: https://doi.org/10.1080/14623940600987015

Zulfikar, T. \& Mujiburrahman (2018). Understanding own teaching: becoming reflective teachers through reflective journals. Reflective Practice, 19(1), 113. DOI: $10.1080 / 14623943.2017 .1295933$ 